See discussions, stats, and author profiles for this publication at: https://www.researchgate.net/publication/331083826

Geographic Information Systems: Should They Be Used in Public Finance Reform Development?: 14th International Conference, ICTERI 2018, Kyiv, Ukraine, May 14-17, 2018, Revised Selec...

Chapter · January 2019

DOI: 10.1007/978-3-030-13929-2_12

1 author:

Tetiana Paientko

Kyiv National Economic University

16 PUBLICATIONS 11 CITATIONS

SEE PROFILE

Some of the authors of this publication are also working on these related projects:

Management of Financial Flows View project

7th International Workshop Information Technology in Economic Research (ITER 2019) View project 


\title{
Geographic Information Systems: Should They Be Used in Public Finance Reform Development?
}

\author{
Tetiana Paientko ${ }^{1[0000-0002-2962-308 X]}$ \\ ${ }^{1}$ Kyiv National Economic University named after Vadym Hetman, Peremohy avenu 54/1, Kyiv \\ 02000, Ukraine \\ tpayentko109@gmail.com
}

\begin{abstract}
Public finance reform is one of the most complex areas of decisionmaking. It requires proper implementing methodology and tools for visualizing possible results of reform in a society. The purpose of this article is to show how geographic information systems (GIS) can be used in the development of reform in the sphere of public finance. GIS could provide a wide range of analysis and better support for ideas of reforms. GIS is useful in cases of public finance reform because it makes it possible to combine statistical, demographical, and geographical analyses. Also, GIS provides necessary visualization that helps ordinary citizens to understand a proposed reform and its aftereffects. GIS can increase transparency and accountability of government, because it is quite difficult to manipulate open map data. The article provides examples of how GIS can be used to justify reforms in public finance, namely, optimizing funding for formal school education and health care. Data from Ukraine was used for the analysis. This choice is due to the presence of radical reforms in this country, citizens' distrust of reforms, and lack of transparency of information about the activities of the public sector. GIS was used to test whether government reforms would comply with European standards of access to schooling and health care for all citizens. The results of the study show that such standards could not be achieved because the government did not take into account the low quality of infrastructure when developing reform programs. GIS is not a perfect tool and several challenges should be also considered. Firstly, the software for GIS must be revised quite often. Secondly, GIS software continues to change and improve over time and there are now several GIS applications that range from being relatively free (having limited tools) to being very expensive (for example, ArcGIS 10.). Thirdly, to follow the idea of increasing transparency, all GIS software should have no conflicts between each other. This means that data from one GIS software can be easily exported into different GIS applications.
\end{abstract}

Keywords: geographic information systems, public finance, reform, health care reform, education reform, taxpayer funds 


\section{Introduction}

Public finance reform is one of the most complex areas of decision-making. At first glance, the problem is related exclusively to the redistribution of taxpayer money. However, for most post-socialist countries, this problem is not easy to solve. This is due to several reasons, one of which is limited financial resources, so it is often difficult for a government to balance the interests of different members of society in the process of financial resource allocation. The second problem is closely related to the former and lies in the institutional immaturity of society, which makes public opinion relatively easy to be manipulated. Institutional immaturity of society has several characteristics. First is the appearance of democracy in form, but without substance. This means that democracy theoretically exists, there is an electoral system in the country, elections are held, but in fact, power belongs to a small group of people who successfully manipulate the elections. Second, there is a merger of business and political power, a result of which is a class of oligarchs that captures not only power over the distribution of financial flows, but also control over state regulators. Third, the society's passivity; people do not believe that change is possible in the country. This is a source of a crisis of trust, where people become skeptical and cynical about any reform in the country. The most sensitive area for crisis of trust is public finance.

This problem is not formed in a single moment, but over time, therefore it cannot be solved quickly. Having carefully studied the process of reform in the public finances of developed countries, it can be concluded that there are several key success factors. First, it is respect for the taxpayers. This means that the government does not hold to a concept of "government money", but rather of "taxpayer money". Expenditures are made as an expression of the will of the taxpayers, not based on the desires of a small group of powerful people. Secondly, there is maximum transparency of reforms meaning that taxpayers can track the use of their money [1]. To achieve a required level of transparency is not a major problem at present. Using modern information technology, accurate information can be available to every member of society. Thirdly, there is an individual approach to the development of a reform mechanism, which ensures high efficiency. In this case modern technology is very useful too.

One of the mistakes of making reform in many developing countries is simply copying the experience of neighboring countries, which can lead to serious errors and irreparable losses of financial resources. The Ukrainian government has been working over the past few years to introduce ideas of fiscal decentralization, but at the same time it is trying to replicate the experience of countries whose decentralization can be considered successful. However, the peculiarities of the Ukrainian economy, the unevenness of regional economic development, and the large physical territory require the development of approaches specific to Ukraine. One such approach can be considered as being the use of geographic information systems (GIS) in support of the economic feasibility of reforms in public finance and the mechanisms for their 
implementation. Also, GIS could be used to increase the level of transparency and accountability, because the performance of GIS is easily understandable even for lay people. Furthermore, it is not very easy to manipulate GIS results after being published, because people understand their own geographic areas.

The most complex areas of reform in public finance are government funding for education and health care. In Ukraine, the share of these in the government has always been quite high (more than 20\%). Funds for these areas have not always been used effectively. This situation has led to a deterioration in the quality of education and health care and should be regarded as an inefficient use of taxpayer funds. The government is proposing a reduction in spending on education and health care as one of the solutions of the current problem. This decision is causing confusion among the majority of citizens, since the income level of the majority of the population is very low. People are concerned that they simply will not have access to education and health care. I see the solution to this problem in a different way. There is no need to reduce government expenditures for education and health care, but funds must be used more efficiently. Taxpayers not only need to understand the essence of the reform, they should be able to track the changes in effectiveness. Since the allocation of funds to finance education and healthcare is related to the territorial aspect, the use of GIS will improve the quality of analytical calculations and minimize the risk of errors.

The paper is organized as follows. The next section explores the theoretical background of GIS use in public finance reform. The third part describes the methodology of the research. The forth part is divided into two subsections. The first presents the possibilities of GIS for optimizing government financing of health care in Ukraine. The second part presents the results of assessing the feasibility of using GIS to justify reforms in the government funding of education. This is followed by a brief discussion on how GIS could help to increase transparency and accountability in public finance reform. The purpose of the article is to show the possibilities of using geographic information systems (GIS) in the development of reform in the sphere of public finance.

\section{Theoretical Background}

Different aspects of public finance reforms are represented in recent publications by prominent authors. A careful study of western economists discussing public finance reform shows that there are two main focuses in this field. The first one is how public finance reform can help to fight corruption through increasing transparency and accountability of the government [2-5]. Economists argue that many reforms in public finance failed because of corruption and lack of transparency and accountability. Furthermore, economists have proven that new approaches in public finance reform are needed to increase efficiency. B. Dressel stated, "Citizen participation and a 
commitment to accountability and transparency have become common in the 'good governance' discourse globally, but the extent of the changes the Philippine government has initiated in terms of how it manages and spends its money is remarkable by any standard" [6]. This means that one of the key factors in increasing the efficiency of public finance reform is citizen involvement in the process of their implementation.

The second focus of recent publications is concerning recognizing the signals of poor quality of reforms and their failures and how the quality of reforms in public finance can be improved [1, 7-12]. It is believed that the quality of public finance reform could be increased by considering the causes that prompted reform in the first place. For example, fiscal crises (in Tanzania, the UK, Canada, Ukraine, Asian economies), political changes (post-socialistic countries), changes in public expectations (Canada, the UK, post-socialistic countries), and post-conflict situations (Rwanda, Burundi, Liberia) all contributed to the shape of specific reforms. The specific cause features are very different, but all of them are intrinsically tied to the quality of peoples' lives in those countries. It means that people should be involved in the reform process and they must have access to the all information on how their funds are being used. The words "their funds" must be used, because those funds are collected as taxes, and as such belong to the taxpayers. Even if funds are raised as government borrowings they are also belong to taxpayers because taxpayers will pay those debts in the future.

Many countries have already started the process of making government activity transparent to the people. A significant impact on this process was made by information technology (IT) development. For example, e-procurement is now standard practice, and this helps to prevent corruption and increase transparency of public fund expenditures. IT could be used in different areas of public finance reform. This is why some economists think that GIS could also be useful in this area. GIS is not completely new in economic science. UK and USA universities started promoting GIS-based economic research in the 1990's [13-15].

At the beginning of this century, GIS became a part of econometric methodology [1617]. Later GIS became useful in research related to demography problems [18-19].

New horizons for GIS are represented in the articles of Anselin, L. and Rey, S.J. (eds) [20], M. Goodchild [21-22], N. Sianko and M. Small [23]. They mentioned that "GIS has been helpful in answering questions relate access to social and health services.... GIS can also be used in demography to study issues related to migration and migration related health problems" [23]. GIS is often used in measuring distances and evaluating access of different groups of people to some facilities [24-25], including public schools [26].

GIS is defined most generally as technology for processing a specific class of information - geographic information. Processing is understood to encompass 
creation, acquisition, storage, editing, transformation, analysis, visualization, sharing, and any other functions amenable to execution in a digital domain [15]. GIS is a very good tool not only for visualization of the Earth's surface information with specific properties, but also as a proper tool for measuring distances considering the quality of roads and characteristics of a particular region (flat fields or mountains). Also, GIS could help to prevent fraud in public expenditures in cases of national disasters, for example floods. The information about the number of houses and their characteristics was in the GIS before a flood, so it easy to calculate how much is needed to compensate people who lost their homes.

Furthermore, GIS can help to create data visualization. GIS data could be easily shared with other researchers and with people who are interested in the results of research. It could help to increase transparency in the public finance reform process, because every citizen could have access to the data, which are presented in an understandable way. GIS helps to create different maps which are good tools to show the interaction between different variables. GIS can help to improve analysis, and this will help to avoid mistakes in developing ideas for reform.

\section{Methodology}

As an example of how GIS can be used in the public finance reform process, health care and education reform in Ukraine has been chosen. The methodology of research was as follows:

1. Create a questionnaire on social networking sites to ask people to express their opinions. Healthcare reform questionnaires were posted on social networks and sent to e-mail addresses of potential respondents. Taking into account that the reform of school education will more affect rural areas, teachers from rural schools were involved in the survey. They have direct contact with parents of students studying in rural schools, this is why they were involved in interviewing work.

2. Analyze peoples' opinion and mapping. Summary tables were created at this stage.

Mapping was done using special software. It allowed the creation of maps to calculate the best locations of schools and healthcare facilities taking into account public opinion. Mapping allows differences in population density, age distribution, disease prevalence, poverty and the ability to access health care facilities or schools to be considered.

The GIS is composed of a regional geographical data base and a collection of spatial models. The regional geographical data base contains a number of thematic map layers including administrative boundaries, roads, bridges; remote sensed data; digital terrain models; and a comprehensive collection of statistical records. The process of 
mapping consists of several stages. First of all, specific healthcare and education variables were defined. For health care facilities those variables are population, age distribution, levels of income, access to public transport, and quality of roads. For schools, those variables are the number of children, their ages, access to public transport, and quality of roads. Secondly, clustering was done to define target groups and possible risk. Thirdly, the mapping was applied. To build a map, the "Open street map" tool was used [27]. This means that only real data was used for analysis and cannot be falsified. The whole map is divided into several sectors. For further analysis buffering must be used. Buffering allows an understanding of how sensitive infrastructure quality and population density impact the study. Various types of buffering could be used (Fig. 1).

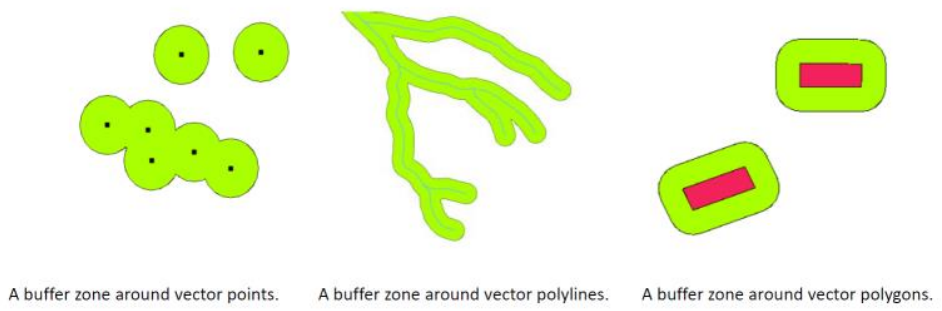

Fig. 1. Buffering in GIS

Multi ring buffering was used here (Fig. 2). Multi ring buffering helps eliminate facilities that have similar accessibility factors and are located close to each other, as shown on the right of Fig. 2. Also this is a good tool for visualizing data, because people are able to see where they live and where a hospital could be located and how fast they could reach it. If such data is kept open to the public, it cannot be manipulated.

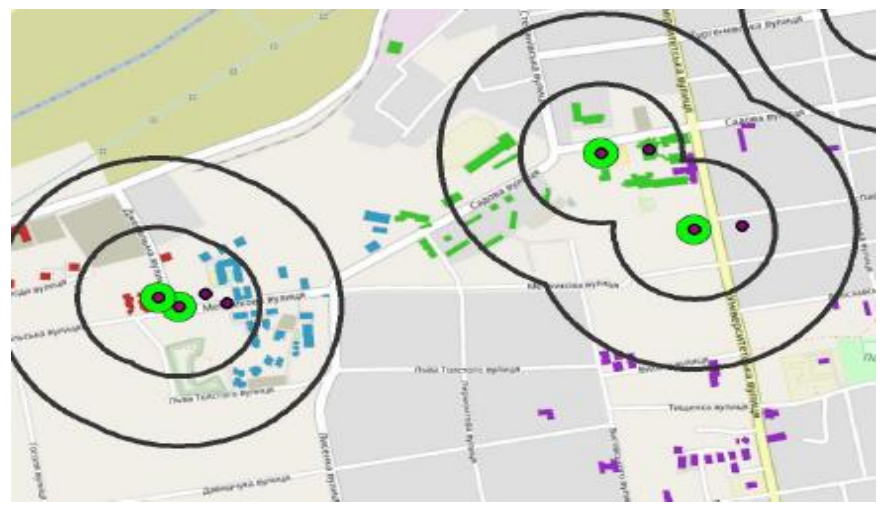

Fig. 2. Multi ring buffering 
Also, every interested citizen can view the map and understand if the governmental decision about facility location (health care or educational) was reasonable or not from their own point of view. If people disagree, they can easily voice their opinion (for example, for reasons of lack of public transportation or bad quality of roads requiring more time to get to a certain facility). Overlay analysis and summary statistics were then used. These tools help calculate optimal distances between hospitals and residences. Overlay and vector analysis also include characteristics of the earth's surface and quality of roads in its calculations.

3. Analyze government proposals for health care and education reform and mapping. Mapping was done considering government decisions on the locations of schools and health care facilities. GIS can be used to identify observations by both characteristics and location and then perform simple statistical operations. Differences between mapping based on public opinion and government decisions were analyzed.

4. Draw conclusions. The most powerful aspect of GIS is arguably its ability to quickly analyze spatial data. This analysis is supported by mapping, and helps with data visualization and can be seen as a way of making data about possible impacts of health care and education reforms transparent and understandable for people.

\section{Efficiency Estimation Procedure}

\subsection{GIS for Health Care Reform}

The first step of the research was the creation of a questionnaire for the social network survey and choose the target group. It should be noted that in Ukraine the age of active users of professional social networks is between twenty and forty-five years old. The target group consisted of five thousand people, $60 \%$ women and $40 \%$ men, with $32 \%$ having a background in economic science, and $68 \%$ with a background in medical care, education, farm production, social services, etc. Because of Ukraine's size, a representative scope can be made using target groups chosen from four oblasts (Kyiv, Zhytomyr, Cherkasy and Chernihiv). The results of the survey are presented in Table 1.

Table 1. Results of survey on public finance reform, $\%$

\begin{tabular}{l|c|c|c|c|c}
\hline \multicolumn{1}{c|}{ Question } & $\begin{array}{c}\text { Strongly } \\
\text { disagree }\end{array}$ & Disagree & Agree & $\begin{array}{c}\text { Strongly } \\
\text { agree }\end{array}$ & $\begin{array}{c}\text { Cannot } \\
\text { decide }\end{array}$ \\
\hline $\begin{array}{l}\text { Do you think that information } \\
\text { about public finance in Ukraine } \\
\text { is not transparent enough? }\end{array}$ & 2 & 3 & 77 & 14 & 4 \\
\hline $\begin{array}{l}\text { Do you think that information } \\
\text { about public finance reforms is } \\
\text { not fair? }\end{array}$ & 1 & 3 & 56 & 26 & 14 \\
\hline
\end{tabular}




\begin{tabular}{l|l|l|l|l|l}
\hline $\begin{array}{l}\text { Do you think that information } \\
\text { about public finance reforms is } \\
\text { not easy to understand? }\end{array}$ & 3 & 4 & 63 & 29 & 1 \\
\hline $\begin{array}{l}\text { Do you think that citizens } \\
\text { should be more involved in } \\
\text { public finance reforms? }\end{array}$ & 3 & 2 & 53 & 15 & 28 \\
\hline $\begin{array}{l}\text { Do you think that citizens can } \\
\text { prevent bad public finance } \\
\text { management? }\end{array}$ & 12 & 29 & 24 & 11 & 24 \\
\hline $\begin{array}{l}\text { Do you think that government } \\
\text { can manipulate information } \\
\text { about public finance? }\end{array}$ & 4 & 3 & 57 & 21 & 15 \\
\hline $\begin{array}{l}\text { Do you think that citizens } \\
\text { should be able to track each }\end{array}$ & 1 & 3 & 83 & 11 & 2 \\
\hline UAH paid as a tax?
\end{tabular}

As can be seen from Table 1, many people are interested in tracking public finance reform, but at the same time roughly $20 \%$ people cannot decide. This group of people cannot make a decision about whether they are interested or not in how government uses their money. It proves the existence of a group of people who are "passive", because they do not understand information about public finance or they do not trust government, or because of other reasons. This is a large percentage for a society that wants to follow democratic ideas. It should be noticed that many people think that information about public finance in Ukraine is not transparent enough and information about reforms in public finance is not fair or not understandable.

The second poll was about the establishment of hospital districts in Ukraine (Table 2).

Table 2. Results of survey on health care reform, $\%$

\begin{tabular}{|c|c|c|c|c|c|}
\hline Question & $\begin{array}{l}\text { Strongly } \\
\text { disagree }\end{array}$ & Disagree & Agree & $\begin{array}{c}\text { Strongly } \\
\text { agree }\end{array}$ & $\begin{array}{l}\text { Cannot } \\
\text { decide }\end{array}$ \\
\hline $\begin{array}{l}\text { Do you think that the } \\
\text { establishment of hospital } \\
\text { districts will improve health } \\
\text { care in Ukraine? }\end{array}$ & 46 & 36 & 10 & 3 & 5 \\
\hline \multicolumn{6}{|c|}{ What kind of risks do you see in establishing of hospital districts: } \\
\hline $\begin{array}{l}\text { Bad access to the health care } \\
\text { facilities }\end{array}$ & 2 & 2 & 71 & 19 & 6 \\
\hline $\begin{array}{l}\text { Absence of medical care in } \\
\text { villages }\end{array}$ & 3 & 3 & 67 & 20 & 7 \\
\hline $\begin{array}{l}\text { Lack of doctors, because they } \\
\text { will leave Ukraine }\end{array}$ & 4 & 6 & 45 & 44 & 1 \\
\hline
\end{tabular}

According to the project on health care reform in Ukraine, a district hospital center must be located in a settlement with 40,000 inhabitants or more and serve a region with at least 200,000 inhabitants. Taking into account the amount of population served, five hospitals should be located in Chernihiv oblast, but according to the 
requirement that the hospital must be located in a town with more than 40,000 inhabitants, this means only one hospital will be funded by the government, and any others will be deprived of funding. In contrast, in the Zhytomyr region, six hospitals should be located there, but according to the minimum population requirement, only three hospitals will be funded by the government, again meaning the remaining hospitals will lose funding. The calculations that were done for Kyiv oblast do not include the population of Kyiv. At least nine hospitals are needed there, but according to the minimum population requirement, only five hospitals will be funded by the government, leaving the remainder unfunded. For the Cherkasy oblast those indicators are six and three respectively (Table 3 ).

Table 3. Main characteristics for hospital districts in selected oblasts

\begin{tabular}{l|c|c|c|c}
\hline Indicators & $\begin{array}{c}\text { Zhytomyr } \\
\text { oblast }\end{array}$ & $\begin{array}{c}\text { Kyiv } \\
\text { oblast }\end{array}$ & $\begin{array}{c}\text { Chernihiv } \\
\text { oblast }\end{array}$ & $\begin{array}{c}\text { Cherkasy } \\
\text { oblast }\end{array}$ \\
\hline Territory, square kilometers & 29832 & 28131 & 31865 & 20900 \\
\hline Population, mln people & 1.240 & 1.735 & 1.056 & 1.231 \\
\hline $\begin{array}{l}\text { Number of towns with a population of } \\
\text { more than 40,000 (equal to the number of } \\
\text { hospital districts in the oblast) }\end{array}$ & 4 & 5 & 2 & 3 \\
\hline
\end{tabular}

It appears that Ukrainian citizens may have reasons to be unhappy with the coming healthcare reform. The district councils involved will decide for themselves how much they need hospitals. The idea of reform is based on the amount of people and does not take into account how people are able to reach the hospitals. Another problem is related to a district council deciding how many hospitals are needed. Because of a lack of funding and differences in the economic development of different districts, this decision becomes almost impossible. The idea of creating hospital districts is not wrong, but its implementation must be based not on the number of people living in a town, but on equal access to the hospital for every citizen. This becomes critical because Ukrainian infrastructure is in very poor condition and public transportation is not universally available.

According to general healthcare requirements, in case of emergency, travel time to a hospital should be within 15-20 minutes. This is not possible to provide if only one or two hospitals are located in a territory of 30,000 square kilometers. This is a case in which GIS could be helpful. One of the most common tools of GIS is spatial analysis. Spatial analysis comprises a set of techniques and tools designed to analyze data in a spatial context. A GIS database captures not only links between properties at the same place, but also such spatial concepts as proximity, containment, overlap, adjacency, and connectedness. Visualization in spatial context (commonly in the form of a map) is an obvious and powerful way of detecting pattern, anomaly, and even causation (M. Goodchild, (2011). It means that by using GIS, the planning of new hospital districts could be improved by better analysis and data visualization. Proper analysis and better visualization will help prove that health care reform is reasonable. This will help decrease tension between government and society and help to build a relationship based on trust, responsibility and accountability. 
Today, several software products are available. The best one is ArcGIS 10 [28]. ArcGIS 10 provides spatial querying, attribute querying, tabular visualization, statistical analysis, advanced mapping, map publishing in pdf format and map printing, etc.

The idea of using GIS in establishing hospital districts is as follows:

1. An analysis of the population in a district and population density is made. At this stage, the rate of population growth, the proportion of children and pensioners, is analyzed. It is important to determine how long the current demand for health care services will remain. It is important to determine the potential need for public health care services for low income people.

2. An analysis of infrastructure, its quality and availability for the population of certain district is made. It is necessary at this stage of the analysis to calculate the average distance from each citizen's home to the potential location of the hospital. Then the average length of time that is necessary for the emergency car to reach the patient must be calculated. The next step is to calculate the average length of time needed to get to the hospital by public transport. It should be noted that GIS allows relatively accurate calculation of time intervals, since it is possible to take into account the terrain and the quality of roads. To prevent data manipulation at the information input stage (for example, the quality of roads may be overestimated), the original data should be publicly available so that any citizen can get acquainted with it. The openness of information at this stage will help prevent the appearance of unreasonable statements about the poor quality of reforms in Ukraine.

3. Visualization could be done through mapping (Fig. 3).

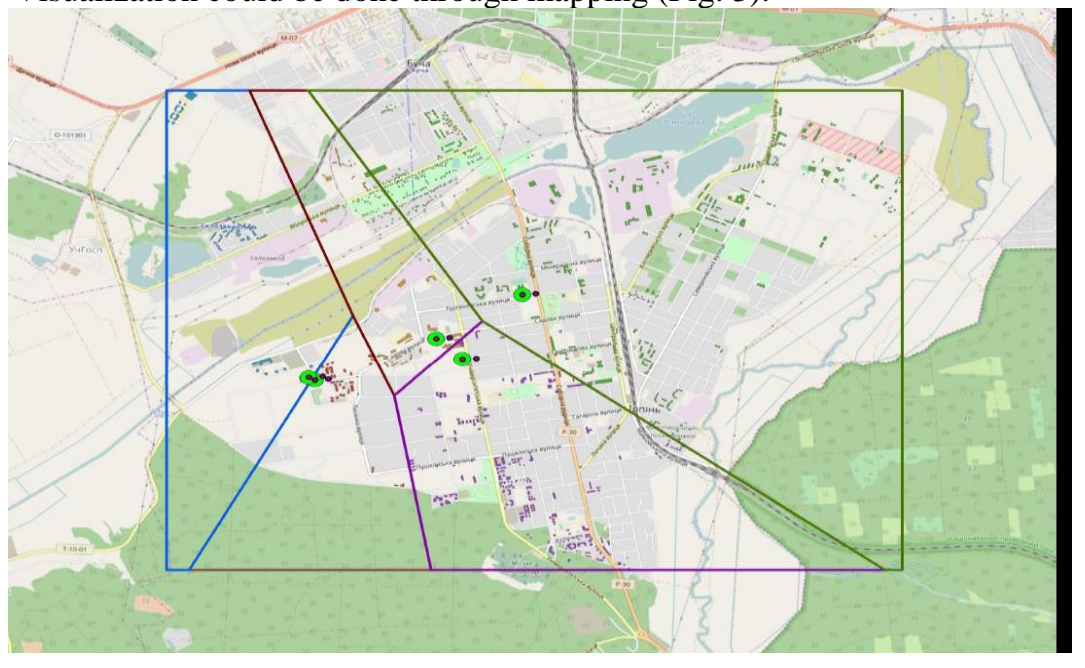

Fig. 3. Results of an analysis of infrastructure quality 
The use of spatial analysis allows not only to combine the processing of geographic and economic data, but also to visually demonstrate the result of calculations. Visual demonstration of reform progress in the public domain helps better explain the expected result of the reforms.

In order to determine the optimal number of hospital districts, the analyzed territories were divided into polygons. The polygons were built taking into account the size of an area, and population numbers and density. Then, using a buffer analysis, the optimal locations for hospitals and the creation of hospital districts around them were determined.

This analysis was completed for four oblasts in Ukraine (Table 4).

Table 4. Results of GIS analysis for Chernihiv, Zhytomyr, Kyiv and Cherkasy oblasts

\begin{tabular}{l|c|c|c|c}
\hline Indicators & $\begin{array}{c}\text { Chernihiv } \\
\text { oblast }\end{array}$ & $\begin{array}{c}\text { Zhytomyr } \\
\text { oblast }\end{array}$ & $\begin{array}{c}\text { Kyiv } \\
\text { oblast }\end{array}$ & $\begin{array}{c}\text { Cherkasy } \\
\text { oblast }\end{array}$ \\
\hline Area square kilometers & 31865 & 29832 & 28131 & 20900 \\
\hline Population, mln people & 1.056 & 1.240 & 1.735 & 1.231 \\
\hline Number of hospital districts & 5 & 6 & 10 & 7 \\
\hline
\end{tabular}

As can be seen in Table 4, the results of GIS analysis show the necessity of establishing a larger number of hospital districts than would be possible according to government requirements. This is because the government project did not include the poor condition of roads in its analysis.

The idea of reforming the health care system is not inappropriate. However, if the government manipulates input data on infrastructure quality, and does not disclose information on the development of the reform and its consequences, it can discredit the actions of the government, and the reform itself.

\subsection{GIS for Formal Education Reform}

The reform of the educational sector is extremely important. The training of the younger generation determines the future of the state. Obviously, Ukrainian education does not correspond today to the modern needs of the individual nor society, the needs of the economy nor to world standards.

That is why the reform envisages a systemic transformation of the education sector, the main objective of which is new high-quality education at all levels: from elementary school to higher education institutions. The main task of education should be the formation of conscious, socially active citizens, capable of ensuring economic growth and cultural development of the country. 
Education reform should cover all areas of education, but formal school education reform is the most problematic. The main problem is the consolidation of schools, and hence the risk of worsening access to education for children who live in rural areas.

Technically, the consolidation of schools is voluntary and aims to improve the quality of education. The closure of small schools is necessary primarily due to the poor quality of education in small schools and the optimization of the educational network. According to official statistics, as of 2016, more than half of the schools in Ukraine were located in rural areas, and 613 schools had an enrollment of up to twenty-five students, which meant that one teacher at a school taught several courses. Also, those schools have a deficiency of material needs.

According to a study by CEDOS, $15 \%$ of rural teachers teach more than three courses, $8 \%$ in small cities, and 5\% in medium and large cities. Almost $30 \%$ of rural schools do not have any computer connected to the Internet, whereas in large cities almost all computers are connected to the Internet.

Politicians claim that the reform offers the united territorial communities (UTCs) the establishment of support schools and their branches. In accordance with decentralization reform, schools are transferred to a UTC, which entails funding from the community budget. That is why the community now has the right to establish schools and determine which school or branch will receive financial support from the community. Accordingly, the decision on the liquidation or reorganization of a school is made by the community on its own.

However, a rapid increase in the number of UTCs without a proportional increase in the transfer of funding from the central government for infrastructure development reduces the motivation of communities to unite and develop education.

In 2016, the transfer of funding from the central government for community infrastructure was one billion UAH and it was distributed among the budgets of 159 UTCs in proportion to community size and population. In 2017, the amount of the transfer of funding from the central government was set at 1.5 billion UAH. It should be noted that financing from the central budget was mainly carried out at the expense of a special fund, and this source of financing is not stable. In addition, the indicated funds were distributed among 366 UTCs, it means that each community received less money in 2017 than in 2016 [29].

Thus, the greatest risk of resistance to the implementation of formal school education reform may arise among villagers and small towns. As was mentioned in the methodology section, the first stage of the research is creating a questionnaire on social networking sites to ask people to express their opinions. Taking into account that the reform of formal school education will more affect rural areas and small towns, teachers from rural schools and from small towns were involved in the survey. They asked parents to answer questions from the questionnaire. It should be noted, that the response from the parents was not very high, only $52 \%$ people filled out the 
questionnaire. Summary results of the survey are presented in Table 5. As can be seen from the table, parents are seriously concerned about the consequences of school reform. They have good reasons for this.

Table 5. Results of the survey about formal school education reform, $\%$

\begin{tabular}{l|c|c|c|c|c}
\hline \multicolumn{1}{c|}{ Question } & $\begin{array}{c}\text { Strongly } \\
\text { disagree }\end{array}$ & Disagree & Agree & $\begin{array}{c}\text { Strongly } \\
\text { agree }\end{array}$ & $\begin{array}{c}\text { Cannot } \\
\text { decide }\end{array}$ \\
\hline $\begin{array}{l}\text { The merger of schools will } \\
\text { destroy the Ukrainian villages }\end{array}$ & 2 & 5 & 48 & 33 & 12 \\
\hline $\begin{array}{l}\text { Many teachers will lose their } \\
\text { jobs }\end{array}$ & 3 & 6 & 33 & 33 & 25 \\
$\begin{array}{l}\text { as a result of school education } \\
\text { reform }\end{array}$ & 1 & 2 & 45 & 43 & 9 \\
\hline $\begin{array}{l}\text { Students from villages will not } \\
\text { have good access to schools }\end{array}$ & 3 & 5 & 46 & 38 & 8 \\
\hline $\begin{array}{l}\text { Schoolchildren will not be able } \\
\text { to } \\
\text { get a quality education, because } \\
\text { parents will not be able afford } \\
\text { textbooks }\end{array}$ & 2 & 4 & 48 & 39 & 7 \\
\hline $\begin{array}{l}\text { Schoolchildren from rural areas } \\
\text { and small towns will not be able } \\
\text { to get quality education in } \\
\text { schools, so they will not be able } \\
\text { to enter universities }\end{array}$ & & & & & \\
\hline
\end{tabular}

Nowadays the management system of school education is constructed in a way that any school in a village or small town receives funding from the local government (raion). The advantages of the present system include the presence of a single monitoring center, the possibility of coordinating the work of school in a certain region, the possibility of staff rotation between schools or redistribution of government financing in cases of unpredicted circumstances requiring urgent financial support (urgent repair of equipment or liquidation of emergency).

The disadvantages of the planned management system are a lack of correlation between the quality of education services and funding. Also, there are cases when the schools that have equal sizes can receive different funding. According to the government's plan, these problems should be solved after the completion of the decentralization reform, when full school management will be transferred to the community level. Under such conditions, the principle of subsidiarity, which means the provision of public services by the government body that is closest to the citizen, must be fully implemented. In our case, it means that the general management and financing of a particular school should be carried out not from the district center (raion), but directly by the executive bodies of the territorial community on which territory a school is located. This is the universally accepted practice of civilized 
democratic societies. This idea may not work now in Ukraine. First, Ukraine is a democratic state only nominally. In fact, public administration is centralized, and citizens are in a passive position and do not take responsibility for themselves. Secondly, even after the completion of decentralization reform, the problem of financing school education in depressed regions will not be solved.

Long-term work is needed to solve these problems. First, the availability of information that every citizen can understand regarding reform effects must be improved. For reforms that are related to territorial interests, GIS is a very important tool. GIS helps to prevent unsound resistance from citizens, and also prevents information manipulation by politicians. Secondly, the merits of reform cannot only be copies of the successes of developed countries. Each country has its own historical and cultural peculiarities of development. These must necessarily be taken into account while developing a reform strategy.

In order to implement the reform of formal school education in Ukraine it is necessary to take into account the availability of school education for children. This means the physical accessibility of the school for children of all ages. It must be considered that long travelling by bus to school is harder for small children, and it is harder for them to get up early. Therefore, the possibility of establishing elementary schools for children from six to ten years of age should be considered, and enlargement should be done among secondary schools.

The optimal number of elementary schools for a given locality can be determined from the vector analysis of GIS (Fig. 4).

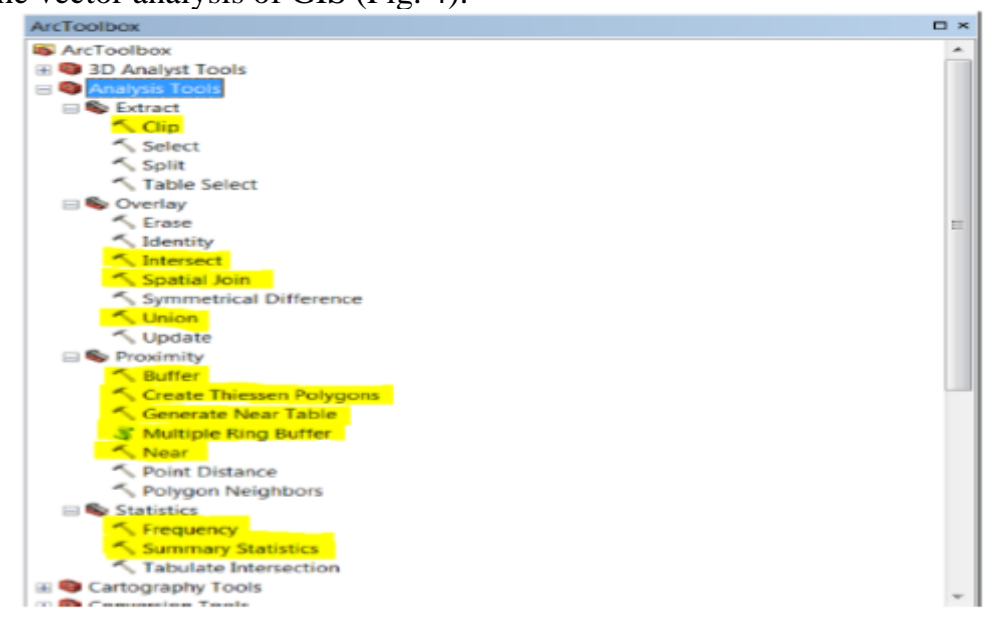

Fig. 4. Tools that were used for vector analysis in GIS

The buffering distance is one of the common tools to determine the best location for a facility. The buffer distance can vary according to numeric values provided in the vector layer attribute table. In our case, the buffer distance depends on the age of 
school children, quality of roads, and the availability of busing. It should be noted that school bus service is not available in every region of Ukraine. This is why two calculations were done. One is for where busing is available, the other where unavailable.

For each region buffers were merged into a single geometric object to avoid overlapping areas. Then multiple buffers at specified distances were created. The next step is calculating distance and additional proximity information between the input features and the closest feature in another layer. To calculate a distance, the "GEODESIC" method was used, because it takes into account the curvature of the spheroid and correctly deals with data near the dateline. Then Thiessen Polygons were created (Fig. 5).

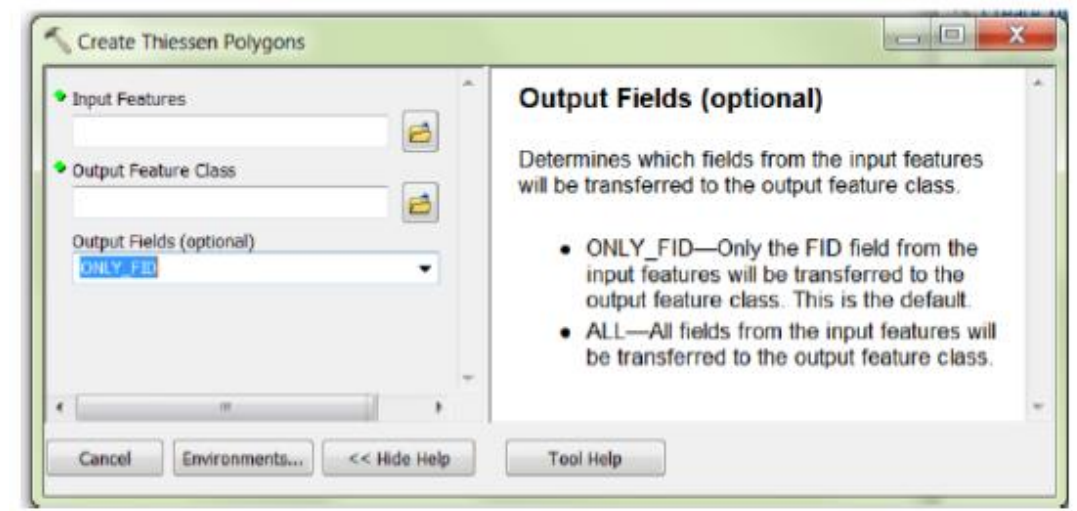

Fig. 5. Creating Thiessen Polygons

The construction of polygons allows the identification of several options for the location of primary schools, taking into account student accessibility. Then a summary of statistic tools were used (Fig. 6).

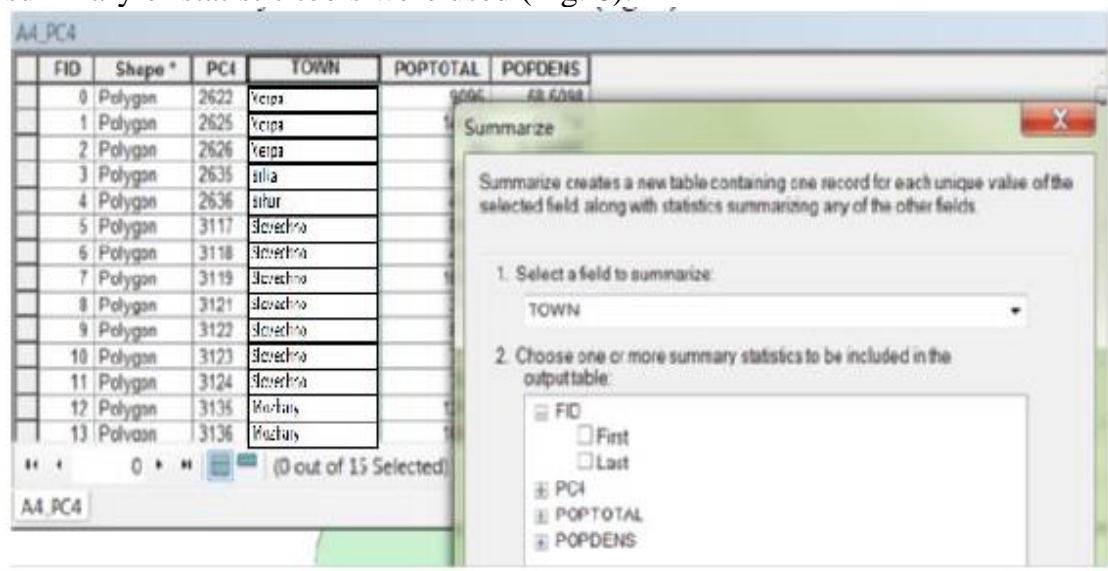

Fig. 6. Summary Statistic 
Statistical GIS tools allow the optimal distance from home to school to be calculated, as well as the travel time that is needed. Analysis of frequency distribution (Fig. 7) shows that for the number of school children from 1 to 100 at least one primary school is needed, for the number from 101 to 1000 at least two primary schools are needed, for the number of children from 1001 to 4000 six schools are needed, and for number of children from 4001 to 12000 at least twelve schools are needed.

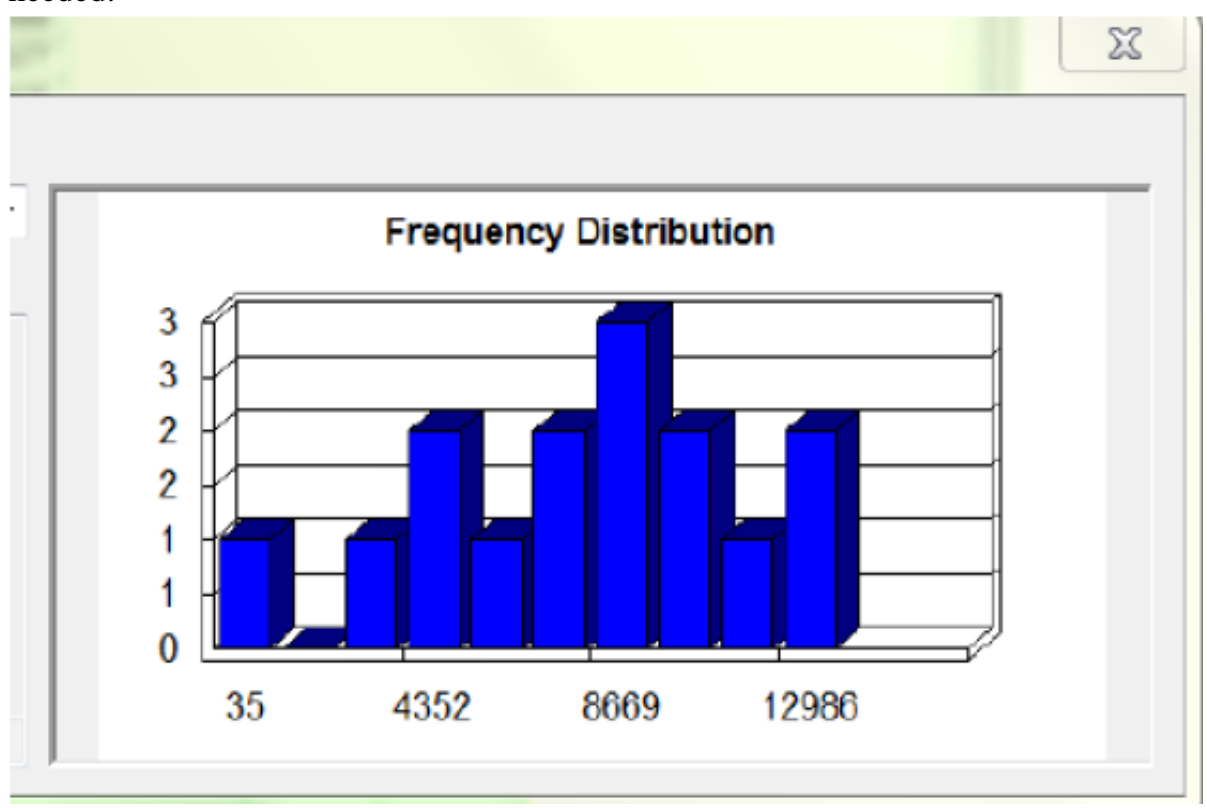

Fig. 7. Frequency Distribution

A calculation was done for Ovruch raion of Zhytomyr oblast. This raion was chosen as an example because it has 144 villages. Raion infrastructure and busing levels can be described as average. The actual number of schools and their location was compared with a GIS calculation. According to the GIS calculations, there was a $17 \%$ discrepancy in the number of needed schools compared to government reform figures. Corrections were made considering the age distribution of school children. As a result of school reform, thirty-six schools will be located in Ovruch raion, with one being primary. According to GIS calculations, forty-two schools are actually needed for Ovruch raion, fourteen being primary schools. The location of twenty-four schools is shown in Figure 8. It can be seen that three schools are located a distance from the larger group of schools. This is explained by the quality of infrastructure; travel is more difficult to the larger grouping. 


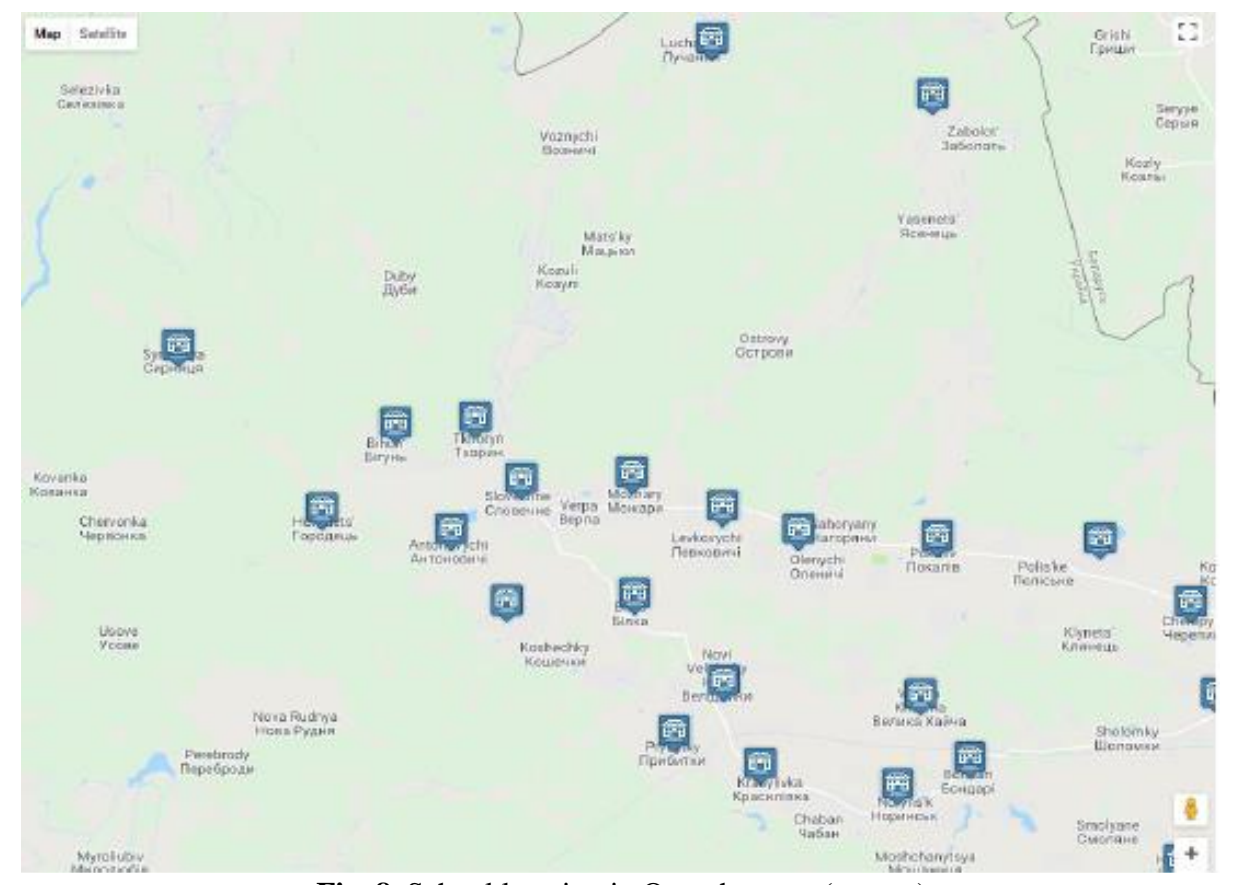

Fig. 8. School location in Ovruch rayon (extract)

These calculations should be made for each district of Ukraine. The results acquired should be used to justify the reform of formal school education. Calculations should take into account the peculiarities of roads, relief, and the real, not planned, number of school buses. It should be noted, that school buses are not available for each region. According to the report of Accounting Chamber of Ukraine, only 791 buses were bought from the planned number of 1600 in 2008-2011. In 2012-2016, 1200 school buses were planned to be bought, but only 326 were bought because of economic and political problems in Ukraine. When the quality of roads is improved, and each region is provided with a sufficient number of school buses, the number of primary schools may be reduced. The decision to reduce the number of primary schools should also be taken based on GIS calculations. These results should be available to local citizens for discussion. Mapping visualization would further help avoid misunderstandings and manipulations in the process of decision making.

\section{Conclusions}

GIS can be a very useful tool in public finance reform development. GIS could provide a wide range of analysis and better support for reform concepts. It also makes possible a combination of statistical, demographical and geographical analyses. Moreover, GIS provides very good visualization that helps ordinary citizens 
understand how reforms would affect them. GIS can increase government transparency and accountability, because it is quite difficult to be manipulated by open source map data.

Reforms in public finance are often linked to the distribution of funding or the tax burden between districts. The complexity of reform justification is caused by the need to work simultaneously with spatial and statistical data. The article provides examples of how GIS can be used to justify reforms in public finance, namely, optimizing funding for formal school education and health care.

The basic idea of health care reform is to improve the quality of medical services and reduce public funding for the maintenance of health facilities. Medical reform involves the creation of hospital districts, the location of which is tied to population size in a certain area, and in the city in which the central hospital will be located. The disadvantage of the reform is that the need to ensure equal access to health care facilities for all citizens was not taken into account. Research conducted with GIS allowed calculating the optimal number of hospital districts for four regions (oblasts) of Ukraine. The GIS-estimated amount is larger than that proposed by the government of Ukraine. This means it is not possible to reduce public expenditures in health care in a short-term. Furthermore, if the government follows trough on its plans in this area, then that result maybe increased resistance from the citizens. Moreover, equal access to health care facilities will be reduced.

The use of open street maps for spatial analysis reduces the risk of manipulation by input data. The presentation of the results of the analysis in the form of maps showing hospital districts reached within a reasonable time from any home in the district would allow reasonable citizen feedback potentially reducing further resistance to the government reforms.

The main goal of education reform is to merge schools, thereby reducing cost. This idea is negatively perceived in villages and small towns. According to the results of the questionnaire, many people have fears that accessibility to education will become more difficult for children living in remote villages. GIS calculations showed that the people's fears are reasonable. The government's calculations did not take into account the time that children must spend on the road to get to school. Also, it was assumed in the government's calculations that all regions were provided with school buses, which is not the case at present.

The results of the calculations presented in the article were made in GIS for one district, taking into account the distribution of children by age, the availability of school buses and the quality of roads. The analysis showed that more schools are needed, some of which are elementary schools. A subsequent decrease in the number of schools, including their merger, should be carried out after improving the quality of roads and providing better access to schools. As in the case of health care reform, the 
use of GIS makes finding the best solutions between reducing funding for formal school education and ensuring that it is accessible to all children possible. Map visualization allows not only a clearer illustration of reform results, but also more people with the ability to comment intelligently on this problem, since such representation of information is understandable for the majority of population.

GIS is not a perfect tool and several challenges should be also considered. Firstly, the software for GIS must be revised quite often. Secondly, GIS software continues to change and improve over time and there are now several GIS applications that range from being relatively free (having limited tools) to being very expensive (for example, ArcGIS 10.). Thirdly, to follow the idea of increasing transparency, all GIS software should have no conflicts between each other. This means that data from one GIS software can be easily exported into different GIS software.

\section{References}

1. Fedosov, V., Paientko, T.: Ukrainian Government Bureaucracy: Benefits and Costs for the Society. Business and Management Studies 3 (2), 8-19 (2017).

2. Allen, R., Schiavo-Campo, S., Garrity, T. Assessing and Reforming Public Financial Management: A New Approach. Washington: World Bank (2004).

3. Gomez, P., Friedman, J., Shapiro, I. Opening Budgets to Public Understanding and

4. Debate. Washington: IBP. Mode of access:

http://www.transparency.cz/pdf/tsr_dstudie_02.pdf.

5. Hedger, E., Kizilbash, A.Z.: Reforming Public Financial Management when the Politics aren't right: A proposal. London: ODI. Mode of access: http://www.odi.org.uk/publications/opinions/89_PFM_politics_Nov07.pdf (2007).

6. $\quad$ Fjeldstad, O.: Anti-Corruption Reforms: Challenges, Effects and Limits of World Bank Support. Background Paper to Public Sector Reform: What Works and Why? Fjeldstad, O.-H. and Isaksen, J. IEG Evaluation of World Bank support, World Bank, (2008).

7. Dressel B. Targeting the public purse: Advocacy coalitions and public finance in the Philippines, Administration and Society, vol. 44, no. 6, pp. 65S-84S (2012).

8. Dorotinsky, W., Pradhan, S.: Exploring Corruption in Public Financial Management. In Campos, J.E. and Pradhan, S. ed. The Many Faces of Corruption. Washington: World Bank (2007).

9. De Renzio, P., Dorotinsky, W. Tracking Progress in the Quality of PFM Systems in HIPCs. Washington: PEFA Secretariat. Mode of access: http://www.pefa.org/report_file/HIPCPEFA\%0Tracking\%20Progress\%20Paper\%20FI

NAL_1207863932.pdf.

10. Andrews, M.: PFM reform: signal failure. Mode of access: http://opinion.publicfinanceinternational.org/2013/03/pfmreform-signal-failure/.

11. Fjeldstad, O.: Taxation and development: A review of donor support to strengthen tax systems in developing countries. WIDER Working Paper No. 2013/010 (2013).

12. Paientko, T.: Behavioral aspects of financial anomalies in Ukraine (2015), CEUR Workshop Proceedings, vol. 1356, P. 214-224 (Indexed by: Sci Verse Scopus, DBLP, Google Scholar). Available: CEUR-WS.org/Vol-1356/ICTERI-2015-CEUR-WS-Volume.pdf 
13. Langran, G.: Time in Geographic Information Systems. London: Taylor and Francis (1992).

14. Laudan, L.: Beyond Positivism and Relativism: Theory, Method, and Evidence. Boulder, CO: Westview Press (1996).

15. Longley, P.A., Goodchild, M.F., Maguire, D.J., Rhind, D.W. Geographical Information Systems: Principles, Techniques, Management and Applications. New York: Wiley (1999).

16. Bialynicki-Birula, I.: Modeling Reality: How Computers Mirror Life. New York: Oxford University Press (2004).

17. Anselin, L., Florax, R.J., Rey, S.J.: Advances in Spatial Econometrics: Methodology, Tools and Applications. Berlin: Springer (2004).

18. Castro, M.C.: Spatial demography: An opportunity to improve policy making at diverse decision levels. Special Issue on Spatial Demography: Population Research and Policy Review 26, 477-509 (2007).

19. Voss, P.R.: Demography as a spatial social science. Special Issue on Spatial Demography: Population Research and Policy Review 26: 457-276 (2007).

20. Anselin, L., Rey, S.J. Perspectives on Spatial Data Analysis. Berlin: Springer (2010).

21. Coodchild, M. New Horizons for the Social Sciences: Geographic Information Systems. Mode of access: http://www.geog.ucsb.edu/ good/papers/334.pdf.

22. Goodchild, M.F. A GIScience perspective on the uncertainty of context. Annals of the American Association of Geographers (2018)

23. Sianko, N., Small, M. The Future of GIS in Social Sciences. Elsevier (2017).

24. Church, Richard. and Alan Murray. Business Site Selection, Location Analysis and GIS. John Wiley and Sons Inc (2009).

25. Combes, Pierre Philippe and Miren Lafourcade. Transport costs decline and regional inequalities: evidence from France, CEPR discussion paper 2894 (2001).

26. Rothstein, Jesse. 'Does Competition Among Public Schools Benefit Students and Taxpayers? Comment,' American Economic Review,97, 2026-2037 (2007).

27. Open street map [Electronic source]: Available at: https://www.openstreetmap.org/\#map=6/48.537/31.168

28. Manual for working with ArcGIS 10 [Electronic source]: Available at: ftp://ftp.puce.edu.ec/Facultades/CienciasExactas/Geoinformatica/MANUALES\%20PARA\%20 LA\%20OPTATIVA/MANUAL\%20ARCGIS\%2010/Manual\%20ArcGis\%2010.pdf.

29. Ministry of Finance of Ukraine [Electronic source]: Available at: https://www.minfin.gov.ua. 